\title{
UNITED STATES AS THIRD-PARTY DEFENDANT UNDER FEDERAL TORT CLAIMS ACT: THE PROBLEM OF MULTIPLE LITIGATION AND A CALL FOR STATUTORY REFORM
}

The United States Government is similar in some respects to a nationwide corporation, performing administrative and distributive functions in every state. ${ }^{1}$ Occasionally, these governmental functions are conducted negligently, creating potential claims against the United States for contribution or indemnity. ${ }^{2}$ While the defendant to a state court tort action will seldom be required to litigate liability and damages more than once when it claims contribution or indemnity from a national corporation, the defendant who asserts such a claim against the United States will be forced to litigate these issues twice unless it can remove the action and implead the United States in the federal court.

The devices of impleader and "vouching in" are often useful in minimizing double litigation in multi-party tort actions. Impleader permits the joinder of the alleged indemnitor or joint tortfeasor as a third-party defendant." "Vouching in" involves notifying the third party of the action and inviting him to participate in the defense against plaintiff's claim. Failure to participate will bind the third party in a subsequent action as to the existence and extent of the liability established in the original action. ${ }^{4}$ While these devices are usually available to the state court defendant asserting a claim against a nationwide corporation, they are not available when the third-party claim is asserted against the United States.

1 Some operations such as the postal service are of necessity conducted in every state. Political considerations also insure that other functions are distributed among the states.

2 Actions against the United States for contribution or indemnity may be maintained under the Federal Tort Claims Act, ch. 753, 60 Stat. 842 (1946), as amended (codified in scattered sections of 28 U.S.C.). See, e.g., United States v. Yellow Cab Co., 340 U.S. 543 (1951) ; Hankinson v. Pennsylvania R.R., 280 F.2d 249 (3d Cir. 1960) ; Chicago, R.I. \& P. Ry. v. United States, 220 F.2d 939 (7th Cir. 1955); United States v. Acord, 209 F.2d 709 (10th Cir.), cert. denied, 347 U.S. 975 (1954).

3 FED. R. CIv. P. 14(a) has served as a model for many state impleader provisions: "At any time after commencement of the action a defendant, as a third-party plaintiff, may cause a summons and complaint to be served upon a person not a party to the action who is or may be liable to him for all or part of the plaintiff's claim against him." See, e.g., ARIz. R. CIV. P. 14 (a); Colo. R. CIV. P. 14(a); DEL. SuPER. CT. (CIv.) R. 14(a); KY. R. CIv. P. 14.01; Mo. Stat. ANN. \$ 507.080 (1966); Nev. R. Civ. P. 14(a); UTAH R. CIV. P. 14(a).

4 Restatement, Judgments \$107, comment c (1942), sets out a rationale for this procedure:

Where a person is under a duty to another to indemnify the other against losses suffered as the result of . . a tort, the indemnitor is entitled to a trial to determine whether his liability has come into existence. He may or may not be under a duty to the indemnitee to defend the action against the latter 
Impleader is proper only where the third party is within the forum state's jurisdiction. In personam jurisdiction can be asserted over a nonresident corporation on the basis of corporate contacts with the state. 5 Since a tort action cannot be maintained against the United States in a state court, an attempt to implead the United States at the state level will fail for want of jurisdiction. ${ }^{6}$

Similarly, an attempt to "vouch in" the United States will also fail. In City of Pittsburgh v. United States, " the Court of Appeals for the Third Circuit held that the United States could not be bound by a state court judgment in a subsequent action for indemnity brought under the Federal Tort Claims Act. ${ }^{8}$ Pittsburgh was found liable in a state court to a pedestrian, injured as the result of a defective sidewalk in front of a building owned and occupied by the United States. Pennsylvania law places primary responsibility for defective sidewalks

and if he is under no such duty he commits no breach by failing to defend. In this event he is entitled, in the subsequent action against him for indemnity, to show that the indemnitee was not subject to liability and hence not entitled to indemnity. On the other hand, since by hypothesis his is the ultimate liability, it is fair that the indemnitee should be able to throw off the burden of the trial and that the indemnitor should respond to a request for assistance by the indemnitee. If he fails to give this assistance at the time when it is of the greatest importance, it is fair that he should abide by the result of the trial. ... [I]f he permits the matter to result in an action his should be the responsibility to see that it does not result in an improper judgment.

The majority of reported cases deal with the process of "vouching in" in the context of indemnity. However, there is authority for the use of this process where the potential claim is for contribution. See Restatement, JudgMenTs \$ 109 (1942); James, Civil Procedure 590 (1965). See also the discussion of the doctrine in Keitz v. National Paving \& Contracting Co., 214 Md. 479, 136 A.2d 229 (1957).

5 In International Shoe Co. v. Washington, 326 U.S. 310, 316 (1945), the Court stated that

due process requires only that in order to subject a defendant to a judgment in personam, if he be not present within the territory of the forum, he have certain minimum contacts with it such that the maintenance of the suit does not offend "traditional notions of fair play and substantial justice."

The states have availed themselves of this power in order to provide a convenient forum for claims of their citizens. An example of the state response to the "minimum contacts" test is ILL. Rev. STAT. ch. 110, \$17 (Supp. 1965):

(1) Any person, whether or not a citizen or resident of this State, who . . . does any of the acts hereinafter enumerated, thereby submits ... to the jurisdiction of the courts of this State as to any cause of action arising from the doing of any said acts:

(b) The commission of a tortious act within this State.

(c) The ownership, use, or possession of any real estate situated in this State.

6 "The United States, as sovereign, is immune from suit save as it consents to be sued . . . and the terms of its consent to be sued in any court define that court's jurisdiction to entertain the suit." United States v. Sherwood, 312 U.S. 584, 586 (1941). See Minnesota v. United States, 305 U.S. 382 (1939). Congress has required that actions under the Tort Claims Act be brought only in the district courts: "[T] district courts ... shall have exclusive jurisdiction of civil actions on claims against the United States for money damages injury or death ...." 28 U.S.C. $\$ 1346$ (b) (1964).

7359 F.2d 564 (3d Cir. 1966). 28 U.S.C.).

8 Ch. 753,60 Stat. 842 (1946), as amended (codified in scattered sections of 
on the abutting landowner, while attaching secondary liability to the municipality. ${ }^{\circ}$ If the city alone is sued, both impleader and "vouching in" are available to prevent multiple litigation if the city wishes to seek indemnity from the landowner. ${ }^{10}$

Pittsburgh attempted to employ both devices. Impleader was denied by the state court which properly recognized that it did not have jurisdiction over the United States. ${ }^{11}$ Pittsburgh also gave notice to the United States and unsuccessfully attempted to remove the action. ${ }^{12}$ After satisfying the state court judgment, Pittsburgh sought indemnity from the United States under the Tort Claims Act. Pittsburgh's motion for summary judgment was granted, the district court declaring that "the action in this Court does not involve retrial of the suit against the City or a rehashing of the negligence case tried in the State court." 13 The court of appeals reversed, insisting that a state court judgment on a jury verdict could not be conclusive in a subsequent action for indemnity against the United States.

The appellate court based its decision on the statutory requirements that the federal district courts have "exclusive jurisdiction of civil actions on ... [tort] claims against the United States" 14 and that "any action against the United States under . . . [the Federal Tort Claims Act] shall be tried by the court without a jury." ${ }^{15}$ The

${ }^{9}$ E.g., City of Philadelphia v. Bergdoll, 252 Pa. 545, 97 Atl. 736 (1916) ; Ferrang v. Michaels, $206 \mathrm{~Pa}$. Super. 43, 211 A.2d 96 (1965) ; Wright v. City of Scranton, $128 \mathrm{~Pa}$. Super. 185, 194 Atl. 10 (1937); Fisher v. City of Philadelphia, $112 \mathrm{~Pa}$. Super. 226, 170 Atl. 875 (1934); Fowler v. Jersey Shore Borough, $17 \mathrm{~Pa}$. Super. 366 (1901).

10 See the discussion of "vouching in" in Fowler v. Jersey Shore Borough, supra note 9, at 372. See also Vinnacombe v. City of Philadelphia, $297 \mathrm{~Pa} .564,568-69,147$ Atl. 826, 827-28 (1929); PA. R. Civ. P. 2252.

11359 F.2d at 565 .

12 Id. at 567. Pittsburgh's petition for removal was denied by the district court because Pittsburgh did not meet the requirement of 28 U.S.C. \& 1446 (1964). Brief for Appellant, p. 3 n.2, City of Pittsburgh v. United States, 359 F.2d 564 (3d Cir. 1966). The action against Pittsburgh was initiated on December 8, 1960. Id. at 2 . In March, 1961, Pittsburgh attempted to implead the United States and subsequently attempted to remove the action. Section 1446(b) then required that "the petition for removal of a civil action ... shall be filed within twenty days after . . . the service of summons upon the defendant . ..." It is evident that Pittsburgh's petition was not timely. The petition would, however, have been denied in any event since the action against Pittsburgh was not removable under the requirements of $\S 1441$ (a) and $1441(\mathrm{~b})$, the primary removal provisions:

(a) . . [A]ny civil action brought in a State court of which the district courts of the United States have original jurisdiction, may be removed by the defendant ....

(b) Any civil action of which the district courts have original jurisdiction founded on a claim or right arising under the Constitution, treaties, or laws of the United States shall be removable without regard to the citizenship or residence of the parties. Any other such action shall be removable only if none of the parties in interest properly joined and served as defendants is a citizen of the state in which such action is brought.

28 U.S.C. $\$ \S 1441$ (a), (b) (1964). The action against Pittsburgh was founded on state law and did not involve diversity of citizenship.

13 City of Pittsburgh v. United States, 236 F. Supp. 809, 811 (W.D. Pa. 1965), rev'd, 359 F.2d 564 (3d Cir. 1966).

1428 U.S.C. $\$ 1346$ (b) (1964).

1528 U.S.C. $\$ 2402$ (1964). 
United States could not have been a party to the state court action. Thus a decision giving effect to the "vouching in" process would deny the United States any opportunity to litigate the basis of its liability. ${ }^{18}$ Furthermore, the court believed that the use of "vouching in" would effectively substitute the judgment of a state court jury for that of a federal judge in contravention of the statutory requirement that tort liability of the United States be determined only by a federal judge. The summary judgment procedure followed in the district court was deemed only a formal compliance with this requirement. ${ }^{17}$

Although the result is correct, the decision presents a problem of multiple litigation by requiring Pittsburgh to relitigate all issues essential to its cause of action. ${ }^{18}$ This result is inconsistent with a philosophy of modern systems of procedure which aims at avoiding the expense,

16 The device of "vouching in" assumes that the third party has notice of the tort action and an opportunity to decide whether to participate in the defense. It can reasonably be assumed that if the third party does not participate, he is willing to abide by the results of the original action. Cf. RESTATEMENT, JUDGMENTS $\$ 107$, comment $c$ (1942). Since only the federal district courts have jurisdiction over Tort Claims Act actions, 28 U.S.C. $\$ 1346$ (b) (1964), an attempt by a United States Attorney to make the United States a party to a state court tort action would be futile, for he could not vest the state court with jurisdiction in this manner. "Where jurisdiction has not been conferred by Congress, no officer of the United States has power to give to any court jurisdiction of a suit against the United States." Minnesota v. United States, 305 U.S. 382, 388-89 (1939). Thus the United States does not have a choice when given notice of a pending state court action and its nonparticipation cannot then be accorded the significance granted to the nonparticipation of a private litigant. Application of the doctrine of "vouching in" against the United States in the circumstances presented by Pittsburgh would therefore be contrary to one premise of that doctrine itself-that the third party has had an opportunity to litigate. An assumption that by its nonparticipation in the state court the United States indicated its willingness to abide by the determinations of that action is improper.

17359 F.2d at 569. The summary judgment in the district court was improper in any event since, even if the Pennsylvania rules regarding "vouching in" could properly be applied to this case, the United States would have been entitled to litigate one important issue-whether the accident was caused by conduct of the city or its agents for which the city was exclusively responsible. If so, the city's liability would be primary rather than secondary. See City of Philadelphia v. Bergdoll, $252 \mathrm{~Pa}$. 545, 548, 97 Att. 736, 737 (1916); Wright v. City of Scranton, 128 Pa. Super. 185, 194 Atl. 10 (1937).

18 The City must prove all these facts not admitted by the United States which are essential to its cause of action, and the United States will have open to it all of the defenses it may offer against the claim, regardless of whether these issues were adjudicated by the state court judgment as between the pedestrian and the City.

359 F.2d at 569.

The problem of multiple litigation presented by Pittsburgh may be mitigated somewhat by recent amendments to the Tort Claims Act providing for increased availability of pre-trial settlement of claims. At present, the Attorney General is authorized to settle claims under $\$ 1346(\mathrm{~b})$ after the commencement of the action only with the approval of the court. 28 U.S.C. $\$ 2677$ (1964). The federal agencies may only settle claims under $\$ 2500$. 28 U.S.C. $\$ 2672$ (1964). Amendments to $\$ 2672$ will permit increased agency settlement of claims without limiting the amount, provided that written approval of the Attorney General be obtained for claims over $\$ 25,000$. 80 Stat. 306 (1966). Thus a defendant in the situation posed by this Comment may be able to secure a settlement of its claim without being required to institute suit. 
inconvenience and possibility of inconsistent verdicts resulting from multiple litigation. ${ }^{19}$

In practice, multiple litigation will probably be necessary in only a limited number of cases; if the action is removable, the United States can be impleaded in the federal court. ${ }^{20}$ The problem is most likely to occur where the plaintiff has an opportunity to sue either the United States or another financially responsible party. Where the alternate defendant appears to be capable of satisfying a judgment, plaintiff's counsel may forego an action against the United States for two reasons. In the state court action against the private defendant, the plaintiff will normally have the right to elect a jury trial. A jury trial is not available in an action under the Federal Tort Claims Act.21 Secondly, the Federal Tort Claims Act limits attorney's fees to $20 \%$ of the judgment, ${ }^{22}$ which may be significantly lower than the average contingent fee in other tort actions. ${ }^{23}$ Plaintiff's attorney may therefore choose to bring his client's action against the alternate defendant in a state court where he may choose a jury and reasonably believe that he is maximizing his client's recovery and his own fee.

The state court defendant with a potential action against the United States may have an opportunity to avoid double litigation of some issues through the use of stipulations. For example, in the action for indemnity or contribution, the United States may be willing to stipulate that the original plaintiff was not contributorily negligent. ${ }^{24}$

19 See, e.g., Clark, Code Pleading 408, 413 (2d ed. 1947) ; Jantes, Civin ProCEDURe 505 (1965) ; Clark, The Infinence of Federal Procedural Reform, 13 LAw \& Contenre. Prob. 144, 155-56 (1948); Holtzoff, $A$ Judge Looks at the Rules After Fifteen Years of Use, 15 F.R.D. 155, 161-62 (1953).

20 See, e.g., United States v. Yellow Cab Co., 340 U.S. 543 (1951) ; Hankinson v. Pennsylvania R.R., 280 F.2d 249 (3d Cir. 1960); Newsum v. Pennsylvania R.R., 79 F. Supp. 225 (S.D.N.Y. 1948).

2128 U.S.C. $\$ 2402$ (1964).

2228 U.S.C. $\$ 2678$ (1964). The $20 \%$ limitation will be inapplicable to claims arising after January 18, 1967. Congress has amended $\$ 2678$ to allow fees up to $25 \%$ of a judgment against the United States under $\$ 1346(\mathrm{~b})$ or an amount received in settlement after the commencement of the action. At present $\$ 2678$ provides that the court will set the attorney's fee in each case. The amendment eliminates this provision, allowing the fee to be set by agreement between the attorney and his client. The amendment also raises the ceiling on attorney's fees applicable to administrative settlement of claims prior to trial from $10 \%$ to $20 \%$. 80 Stat. 306 (1966).

Section 2678 continues to provide that an attorney who charges more than the statutory limit is subject to a fine of $\$ 2,000$ and imprisonment for one year.

23 It has been estimated that the average contingent fee in Massachusetts is $30 \%$. Hughes, The Contingent Fee Contract in Massachusetts, 43 B.U.L. REV. 1, 13 (1963). The suggested fee schedule of the Michigan State Bar Association sets a figure of $331 \% \%$ for cases actually tried and $40 \%$ for those appealed. Mich. S.B.J., Aug. 1966, p. 46. See also Gair v. Peck, 6 N.Y.2d 97, 160 N.E.2d 43, 188 N.Y.S.2d 491 (1959).

24 See Hankinson v. Pennsylvania R.R., 280 F.2d 249 (3d Cir. 1960). A railroad sought indemnity from the United States for the amount paid to an employee in settlement of a claim arising under the Federal Employers Liability Act where the employee was injured because of a defect in a government mailbag. In the action for indemnity the railroad and the government stipulated that the settlement figure was reasonable and that the railroad would thus not be required to litigate the issue of extent of damages. 
The willingness of the United States to enter into such stipulations may depend upon its confidence in the quality of the defense offered in the original action. ${ }^{25}$

Limited participation by the United States in the state court action-ranging from informal consultation with defense counsel to participation as amicus curiae ${ }^{26}$ - might serve to eliminate doubts as to the quality of the original defense. Although Pittsburgh clearly demands independent adjudication of the liability of the United States in a federal court, it would not appear to preclude participation in the state court aimed only at limiting issues by consent.

While flexible and informal, this solution is unsatisfactory because it is based on voluntary action by the United States designed to give practical assistance to one who will subsequently be an adverse party. The United States cannot be compelled to act out of self-interest-it need not fear that its nonparticipation in the state court will bind it in the later action for indemnity or contribution. Indeed, if this approach were followed, the United States would be subject to some of the same problems of expenditure of time and resources arising from double litigation that are imposed on the defendant by Pittsburgh.

A better solution to the problem is removal of the original action by impleading a government officer or employee who, under the particular fact situation, might be considered responsible for the activity giving rise to the claim against the United States. ${ }^{27}$ Since claims against government officers and certain employees are removable, the

25 The government's attitude in this regard is well illustrated by its position in Pittsburgh: "[T] $]$ he United States by being compelled to remain aloof was forced to risk a judgment adverse to its interest resulting perhaps from inadequate or incompetent defense by one who has a plainly secondary interest." Brief for Appellant, p. 9 n.6, City of Pittsburgh v. United States, 359 F.2d 564 (3d Cir. 1966).

Familiarity with the nature of the initial tort action by a representative of the Justice Department or of the federal agency involved in the particular tort situation might also have the effect of increasing the likelihood of settlement before the commencement of an action against the United States. This will be increasingly true after January 18, 1967, when amendments to the Tort Claims Act, improving the possibility of pre-trial administrative determination of claims against the United States, become effective. See note 18 supra.

26 An amicus curiae is generally not considered a party to the action and will not be bound thereby. See, e.g., City of Winter Haven v. Gillespie, 84 F.2d 285, 287 (5th Cir.), cert. denied sub nom. Hartridge-Cannon Co. v. Gillespie, 299 U.S. 606 (1936); Village of North Atlanta v. Cook, 219 Ga. 316, 321, 133 S.E.2d 585, 589 (1963). The United States has been granted leave to appear as amicus in state courts where essential interests of the government were at stake. See, e.g., City of New Rochelle v. Republic of Ghana, 44 Misc. 2d 773, 255 N.Y.S.2d 178 (Sup. Ct. 1964) (foreign relations); Dawe v. Silberman, 185 Misc. 335, 56 N.Y.S.2d 902 (Munic. Ct. N.Y. 1944) (wartime economic controls). While the United States cannot become a party to the action in the state court, see note 16 supra, there is no prohibition against participation short of actually becoming a party, which will not bind the United States thereafter.

27 The impleaded government officer or employee must be one who would be liable as an individual in each particular situation. In some cases the identification of such an individual may be difficult. Of course, many cases are likely to arise from automobile accidents and the identification of the government driver should not be difficult. 
addition of such a claim to the state court action may result in the removal of the entire action.

Actions against officers of the United States are removable under 28 U.S.C. $\$ 1442$, which provides:

(a) A civil action or criminal prosecution commenced in a State court against any of the following persons may be removed by them to the district court of the United States for the district and division embracing the place wherein it is pending:

(1) Any officer of the United States or agency thereof, or person acting under him, for any act under color of such office.... ${ }^{28}$

Tort actions against government employees arising out of motor vehicle accidents ${ }^{29}$ are removable under 28 U.S.C. $\$ 2679$ (d).$^{30}$ The government driver is required to notify his superiors of the pending action ${ }^{31}$ and upon certification by the Attorney General that the defendant was acting within "the scope of his employment," the case is removed and the United States is substituted as the defendant. ${ }^{32}$ A claim which meets the requirements of either section 1442 or section 2679 (d) is removable despite the absence of diversity of citizenship or a federal question. ${ }^{33}$

Since neither section 1442 nor section 2679 deals expressly with third-party claims, ${ }^{34}$ the basic interpretive problem is whether a thirdparty claim, which would be removable under either section if brought as a separate action, will trigger the removal of the entire action when

2828 U.S.C. \$1442(a)(1) (1964). See, e.g., Coxsey v. Hallaby, 334 F.2d 286 (10th Cir. 1964) (administrator of FAA); Blitz v. Boog, 328 F.2d 596 (2d Cir.), cert. denied, 379 U.S. 855 (1964) (doctor attached to VA hospital) ; Allman v. Hanley, 302 F.2d 559 (5th Cir. 1962) (doctors attached to Air Force); Poss v. Lieberman, 299 F.2d 358 (2d Cir.), cert. denied, 370 U.S. 944 (1962) (HEW claims agent); Bradford v. Harding, 284 F.2d 307 (2d Cir. 1960) (forty-six members of a federal grand jury, a United States Marshal, two United States Attorneys, a federal judge, a United States Postal Inspector and a New York City detective); Sarner v. Mason, 228 F.2d 176 (3d Cir. 1955), cert. denied, 351 U.S. 924 (1956) (Federal Housing Commissioner).

2980 Stat. 306 (1966), 28 U.S.C. $\$ 2679$ (b) (Supp. -).

30 See Lipinski v. Bartko, 237 F. Supp. 688 (W.D. Pa. 1965) ; Van Dorn v. Huffman, 221 F. Supp. 285 (E.D. I1i. 1963); Adams v. Jackel, 220 F. Supp. 764

(E.D.N.Y. 1963) ; Gustafson v. Peck, 216 F. Supp. 370 (N.D. Iowa 1963).

3128 U.S.C. $\$ 2679$ (c) (1964).

3228 U.S.C. $\$ 2679$ (d) (1964).

33 [T] he federal government has a special interest in . . . [claims against government officers] which justifies the granting of removal jurisdiction to the federal courts in such cases. Congress has not in $\$ 1442$, as in $\S 1441$, required that the case be one over which the court have original jurisdiction in order for the defendant to obtain removal.

Poss v. Lieberman, 299 F.2d 358, 359 (2d Cir.), cert. denied, 370 U.S. 944 (1962). Neither $\$ 1442$ nor $\$ 2679$ (d) requires a jurisdictional amount for removal.

34 The language of each section is broad enough to encompass third-party claims.

Section 1442 provides for the removal of a "civil action"; $\$ 2679(d)$ speaks of a "civil action or proceeding." 
it is joined by impleader to an otherwise nonremovable claim. Two methods of interpretation are possible. The first is to read sections 1442 and 2679 (d) in conjunction with 28 U.S.C. $\$ 1441$ (c), which provides for removal where there is joinder of removable and nonremovable claims. The second is to read sections 1442 and 2679 (d) independently of any other removal provisions and to interpret them in the light of their language and purposes.

If these sections are to be read with section 1441 (c), there is little likelihood that the entire action can be removed on the basis of the third-party claim against the government officer or employee because of restrictive judicial interpretations of the language of section 1441(c). Section 1441(c) provides:

Whenever a separate and independent claim or cause of action, which would be removable if sued upon alone, is joined with one or more otherwise non-removable claims or causes of action, the entire case may be removed and the district court may determine all issues therein, or, in its discretion, may remand all matters not otherwise within its original jurisdiction. ${ }^{35}$

The third-party claim, removable under either section 1442 or section 2679(d), will satisfy the statutory requirement of a claim "which would be removable if sued upon alone." Two problems are then presented: (1) Does the language "is joined" in section 1441(c) contemplate only a joinder of claims by the plaintiff? (2) Is the third-party claim for indemnity or contribution a "separate and independent claim or cause of action"?

Section 1441(c) has been interpreted to encompass only the joinder of claims by the plaintiff, an interpretation based on a finding that section 1441 (c) was designed to limit removal. ${ }^{36}$ Applied to a situation where a third-party claim against a government officer or

3528 U.S.C. $\$ 1441$ (c) (1964).

36 This interpretation seems to have had its inception with the publication of MOORE, Judicial CODE-CoMmentary (1949). Professor Moore stated:

[S] ince there is no warrant for removal of an action except insofar as some statute gives it, since the removal statute may properly be construed strictly and against jurisdiction, and since it authorizes removal only in the case where there has been a joinder of two or more causes of action and this joinder may properly be confined to a joinder of claims by the plaintiff, we do not believe that any claim introduced into the action by counterclaim, cross-claim, thirdparty claim, intervention, or garnishment should afford the basis for removal.

Id. at 252. Courts have generally followed this pronouncement. See, e.g., White v. Baltic Conveyor Co., 209 F. Supp. 716 (D.N.J. 1962); Burlingham, Underwood, Barron, Wright \& White v. Luckenbach S.S. Co., 208 F. Supp. 544 (S.D.N.Y. 1962); Shaver v. Arkansas-Best Freight Sys., 171 F. Supp. 754 (W.D. Ark. 1959) ; Sequoyah Feed \& Supply Co. v. Robinson, 101 F. Supp. 680 (W.D. Ark. 1951); cf. Shamrock Oil \& Gas Co. v. Sheets, 313 U.S. 100 (1941). Contra, Rafferty v. Frock, 135 ·F. Supp. 292 (D. Md. 1955) ; Industrial Lithographic Co. v. Mendelsohn, 119 F. Supp. 284 (D.N.J. 1954); President \& Directors of Manhattan Corp. v. Monogram Associates, 81 F. Supp. 739 (E.D.N.Y. 1949). 
employee is joined with a nonremovable claim, this doctrine would prohibit the removal of any part of the action. The statutory language "separate and independent claim or cause of action" presents a second problem. It has been interpreted to require almost complete independence of the two claims before section 1441(c) removal may be invoked. In American Fire \& Cas. Co. v. Finn, ${ }^{37}$ the Supreme Court interpreted the phrase to conform to the evident congressional intent to limit removal. The Court declared:

The effectiveness of the restrictive policy of Congress against removal depends upon the meaning ascribed to separate and independent cause of action. ${ }^{38}$

$[\mathrm{W}]$ here there is a single wrong to plaintiff, for which relief is sought, arising from an interlocked series of transactions, there is no separate and independent claim or cause of action under $\S 1441(\mathrm{c})$. $^{39}$

The addition of the word "independent" gives emphasis to congressional intention to require more complete disassociation between the federally cognizable proceedings and those cognizable only in state courts before allowing removal. ${ }^{40}$

While a tort action and a third-party claim for contribution or indemnity joined with it need not factually arise out of an "interlocked series of transactions," it is clear that the two claims are closely associated legally. The third-party cause of action is dependent upon a determination of liability in the initial tort action. This dependence, combined with the Supreme Court's apparent emphasis of the word "independent" and the remand provision of section 1441(c), leads to the conclusion that a third-party claim cannot be considered a "separate and independent claim or cause of action." 41 The district court

37341 U.S. 6 (1951).

88 Id. at 12. The Court found authority for the proposition that Congress intended to "abridge" the right of removal by amending $\$ 1441(\mathrm{c})$ in a statement in the Reviser's Notes to that section that the amendment "will somewhat decrease the volume of Federal litigation." Id. at 10. This same statement is included in the House Report explaining the changes to be made in Title 28. H.R. REP. No. 308, 80th Cong., 1st Sess. A133 (1947). However weak this bit of legislative history is to support the conclusion that Congress intended to restrict the right of removal, this idea, in combination with the doctrine that removal statutes are to be strictly construed, has taken root in the judicial interpretation of $\$ 1441(\mathrm{c})$. See note 36 supra.

$39 \mathrm{Id}$. at 14.

$40 \mathrm{Id}$. at 12.

41 Courts which have faced the problem of $\S 1441$ (c) removal based on a removable third-party claim have generally decided that the case is not removable because a third-party defendant cannot remove under this section. See note 36 supra and accompanying text. However a few courts have gone beyond this issue and have chosen to decide whether a third-party claim can be "separate and independent." See Rager v. Crampes, 223 F. Supp. 346 (W.D. Ky. 1963); Manternach v. Jones County Farm Serv. Co., 156 F. Supp. 574 (N.D. Iowa 1957); Marshall v. NAVCO, Inc., 152 F. Supp. 50 (S.D. Tex. 1957); Shaver v. Arkansas-Best Freight Sys., 171 F. Supp. 754 (W.D. Ark. 1959) (dictum-case decided on the joinder issue). See 
is empowered by section 1441 (c) to remand all matters not within original federal jurisdiction. ${ }^{42}$ One of the prerequisites for section 1441 (c) removal is the independence of the claims. Presumably each of these independent claims should be capable of surviving separation by the remand of the nonfederal claim. The survival of such a separation is impossible in an impleader situation because the third-party claim is dependent on the tort action. Impleader accelerates the accrual of the third-party cause of action. Remand of the original tort action would leave the third-party claim hanging meaninglessly in the federal court. For this reason it is difficult to conceive of a third-party claim for contribution or indemnity as "separate and independent" consistently with the structure of section $1441(\mathrm{c}) .^{43}$

Since under section 1441 (c) the entire action must be removable if any part of it is to be removable, the result of reading sections 1442 and 2679 (d) in conjunction with section 1441 (c) is to prevent the removal of any part of the action by the third-party defendant. This result is at variance with the obvious congressional intent in enacting sections 1442 and 2679 (d).

Because a government officer or employee can secure removal of an action against him under section 1441 if the case meets the requirements of that section, it is evident that in enacting sections 1442 and 2679 (d) Congress sought to grant a broader right of removal unencumbered by the requirements of section 1441. The removal provision of section 2679 (d) was enacted to implement the general purpose of section 2679-to make an action against the United States the exclusive remedy for a plaintiff injured by a government motor vehicle. Congress chose to accomplish this purpose by permitting the removal of actions against government drivers and the substitution of the United States as a party in the district court. ${ }^{44}$ Since such an

also Westwood Dev. Co. v. Higley, 266 F.2d 555, 558 (5th Cir. 1959), where a thirdparty claim was described for removal purposes as "no action at all. It was an action over, a warning action, a stand by and defend notice. . . . In these circumstances, 'no separate and independent claim or cause of action' was presented."

42 "[T] he district court may determine all issues therein, or, in its discretion, may remand all matters not otherwise within its original jurisdiction." 28 U.S.C. §1441 (c) (1964).

43 See cases cited in note 41 supra. This analysis is not always explicit in the cases. The courts have decided either that the third-party claim is not a "claim or cause of action" at all or that the third-party claim and the primary action arose out of an "interlocked series of transactions." This second analysis may be valid where the action is for contribution but need not be valid where the claim is for indemnity. If the interlocking required is a factual connection, many indemnity actions, such as those found in products liability cases, would not be considered interlocked.

44 In providing for the removal of claims against government drivers, Congress sought to protect the drivers from having to satisfy judgments out of their own resources. Another alternative would have been for Congress to provide for the indemnification of the drivers for judgments rendered against them in the state courts. This idea was rejected on the ground that it would subject the United States to the payment of a judgment determined by a state court jury rather than by a federal judge. See H.R. REP. No. 297, 87th Cong., 1st Sess. 7-8 (1961). 
action against the United States falls under the Tort Claims Act, removal to the district court is consistent with the grant of "exclusive" jurisdiction to those courts by section $1346(\mathrm{~b})$.

Unlike section 2679(d), section 1442 is not directed toward the solution of a specific problem arising out of a recurring fact pattern. Rather, section 1442 is aimed at a more general evil-the possibility that the performance of the functions of the federal government will be hampered or disrupted by lawsuits brought against federal officials in the state courts. ${ }^{45}$ Furthermore, an unrestricted right of removal secures for officers of the federal government the protection of the federal courts which may be more sympathetic than the state courts to the doctrines of governmental privilege and immunity for federal officials. ${ }^{48}$

In circumstances where a third-party claim against a government officer is joined with an otherwise nonremovable tort claim, the purposes of sections 2679(d) and 1442 would be frustrated if the removability of the entire action were to be determined by the requirements of section 1441 (c). The more satisfactory approach is to read sections 1442 and 2679 (d) entirely apart from section $1441(\mathrm{c}){ }^{47}$ This does violence to neither the language nor the structure of the removal statutes. The reference in section 1441 (c) to a "claim removable if sued upon alone" can be read to apply only to claims removable under the terms of sections 1441 (a) and (b). Interpreted in this manner, sections 1442 and 2679 (d) will permit the removal of an entire action to be triggered by the joinder of a third-party claim against a government officer or employee. This would permit the state court defendant facing the possibility of multiple litigation to

45 See Colorado v. Symes, 286 U.S. 510 (1932) ; Tennessee v. Davis, 100 U.S. 257 (1879); Yeung v. Hawaii, 132 F.2d 374 (9th Cir. 1942); Jones v. Elliott, 94 F. Supp. 567 (E.D. Va. 1950); Application of Shumpka, 268 Fed. 686 (N.D.N.Y. 1920). With the exception of Jones $v$. Elliott, these cases deal with predecessors of $\S 1442$.

46 The theory underlying the doctrines of official immunity and privilege bears an analogous relationship to the theory underlying the decision to permit removal of claims against federal officers. See Barr v. Matteo, 360 U.S. 564, 571 (1959).

47 Since subsection (c) is a part of section 1441, we believe that it applies only when the separate and independent claim is removable under the general article, section 1441 (a) and (b), i.e., on the basis of diversity or federal question. Consequently, section $1441(\mathrm{c})$ should not be applied to actions removable under, e.g., section 1442 (suits against federal officers).

Moore \& VanDercreek, Multi-party, Multi-Claim Removal Problems: The Separate and Independent Claim Under Section 1441(c), 46 Iowa L. REv. 489, 512 (1961); 14 Sw. L.J. 535, 538 (1960). Courts apparently have accepted the view that the requirements of the general removal statute need not be read into cases involving $\S 1442$. The general requirement under $\$ 1441$ is that all defendants must join in the petition for removal. This rule has been held inapplicable to $\$ 1442$. E.g., Bradford v. Harding, 284 F.2d 307 (2d Cir. 1960). Likewise, the rule applicable to \$1441 that the facts demonstrating the right to remove must appear on the face of the plaintiff's complaint has been held not to apply to removal under $\$ 1442$. Poss $v$. Lieberman, 299 F.2d 358 (2d Cir.), cert. denied, 370 U.S. 944 (1962). Not all courts have taken this position. Some have looked to the requirements of $\$ 1441$ (c) for guidance when faced with multi-claim removal under \$1442. See Westwood Dev. Co. v. Higley, 266 F.2d 555 (5th Cir. 1959). 
implead a government official and thus secure removal of the action and ultimately joinder of the United States. ${ }^{48}$

Joinder of an official or employee represents a rather circuitous solution to the problem. A more direct and effective solution is an amendment to the Tort Claims Act specifically designed to permit removal of a tort action on the basis of an anticipated claim against the United States arising out of that action. Such an amendment might be drafted as follows: ${ }^{49}$

A defendant to a civil action or proceeding in a state court who claims that the United States is or may be liable to him under section 1346 (b) for all or part of the plaintiff's claim against him shall notify the United States Attorney for the district embracing the place where the state court action is brought. Such notice shall consist of copies of the pleadings filed in the state court and a short and plain statement of the claim to be asserted against the United States.

A copy of such notice shall be filed with the district court for the district embracing the place where the state court action is brought and shall be considered a petition for removal and joinder of the United States as a third-party defendant. The United States may oppose this motion on the grounds that it fails to state a claim against the United States under section $1346(\mathrm{~b})$. If at any time before trial, it appears that no claim is stated against the United States, the action shall be remanded.

This proposed amendment would permit the defendant to remove the action and implead the United States, enabling him to litigate his claim against the government according to the terms dictated by

48 Although $\S 1441$ (c) permits the removal of an action where two relatively independent claims are joined, removal of an entire action under $\$ 1442$ might properly be limited to those cases where the two claims share so many characteristics that judicial economy is promoted by removal to the federal court so that the relevant litigation may be completed in one trial.

A recent amendment to the Tort Claims Act provides that no action may be instituted against the United States until the claim has been presented to the appropriate federal agency for settlement and denied in writing by that agency. 80 Stat. 306 (1966). The removal device discussed here would result in the impleader of the United States upon removal and would thus present no opportunity for the defendant to present his claim to the appropriate agency prior to the commencement of the action against the United States. The amendment provides for such a situation by excepting from its provision claims against the United States asserted under the Federal Rules of Civil Procedure by third-party complaint. Ibid.

49 Certain other federal statutes have been designed at least in part to promote judicial economy. For example, the Federal Interpleader Act, 28 U.S.C. § 1335 (1964), grants federal jurisdiction to interpleader actions-a development which has the effect of decreasing multiple litigation since where two claimants are residents of different states, it may be impossible to interplead them successfully in the state court. See Chafee, The Federal Interpleader Act of 1936, 45 Y ALE L.J. 963 (1936). Another statute which has the effect of reducing multiple litigation is 28 U.S.C. $\$ 1338$ (1964), 
Congress-in the federal district courts before judges sitting without juries. ${ }^{50}$

Although this will solve the defendant's problem of multiple litigation, this solution may be objectionable to the plaintiff. Having originally chosen the forum, plaintiff may contend that removal deprives him of a convenient or friendly place for trial. Removal may result in trial in a different city-perhaps in a metropolitan center some distance from plaintiff's home or the place where the tort occurred. The proposed statute minimizes but does not eliminate this problem by making the proper district court depend upon plaintiff's initial choice of forum-the action would be removable only to the district court for the district embracing the place where the action is pending. ${ }^{51}$

The plaintiff may also fear that the joinder of his claim with a claim under the Tort Claims Act will deprive him of a trial by jury. The Tort Claims Act prohibition against jury trials will not, however, apply to plaintiff's claim against the defendant. It merely applies to the defendant's third-party claim against the United States. The Federal Rules of Civil Procedure provide flexibility in handling related actions. If necessary, one action may be tried to a judge and the

dealing with the jurisdiction of the federal courts over cases involving patents, copyrights, trademarks and unfair competition:

(a) The district courts shall have original jurisdiction of any civil action arising under any Act of Congress relating to patents, copyrights and trade-marks. Such jurisdiction shall be exclusive of the courts of the states in patent and copyright cases.

(b) The district courts shall have original jurisdiction of any civil action asserting a claim of unfair competition when joined with a substantial and related claim under the copyright, patent or trade-mark laws.

The Reviser's Note to this section, 28 U.S.C. $\$ 1338$ (1964), indicates that subsection (b) was enacted to avoid piecemeal litigation. This section is especially analogous to the problem treated in this Comment since, as in actions under the Tort Claims Act, patent and copyright cases are within the exclusive jurisdiction of the district courts so that a claim for unfair competition cannot be joined with a claim arising under the federal copyright laws in a state court.

Even more important for the purposes of this Comment is the congressional intention to amend the Tort Claims Act so as to "ease court congestion and avoid unnecessary litigation" by providing for increased possibility of settlement of claims against the United States. H.R. REP. No. 1532, 89th Cong., 2d Sess. 6 (1966); 80 Stat. 306 (1966). Congress was concerned with the necessity for instituting suit where the claim against the United States was for more than $\$ 2500$ even though the agency involved would have been willing to settle the claim. "The filing of the suit and the consequent expense to the Government in preparing the case would appear to be unnecessarily involved when the case is a proper one for early settlement." H.R. REP. No. 1532, 89th Cong., 2d Sess. 8 (1966).

In view of this congressional interest in some of the practical aspects of Tort Claims Act litigation, it is not unrealistic to hope for some statutory remedy to the problem of multiple litigation discussed here.

5028 U.S.C. $\$ 1346$ (b) (1964); 28 U.S.C. \$2402 (1964).

51 Venue under the Tort Claims Act is proper in the district embracing the place where the negligent act occurred as well as where the plaintiff resides. 28 U.S.C. $\S 1402(2)$ (b) (1964). The proposed statute departs from this formula to minimize possible inconvenience to the plaintiff. 
other simultaneously tried to a jury. ${ }^{52}$ Because of this flexibility, the no-jury trial provision of the Tort Claims Act need present no barrier to the joinder of the United States as a third-party defendant to a tort action. ${ }^{53}$

This flexibility of procedure will not eliminate one problem raised by multiple litigation. Merely bringing the action into the federal court will not automatically preclude the possibility of inconsistent verdicts. Where the split trial procedure is used, plaintiff's action against the defendant being tried to the jury with the thirdparty action against the United States being tried to the judge, it is theoretically possible that inconsistent verdicts on the issue of defendant's liability will result. The judge will send the question of defendant's liability to the jury where in his view reasonable men might differ as to the result. This decision does not require that the judge, as the trier of fact in the third-party action, find the United States liable over to the defendant. The judge can consistently permit the jury to find the defendant liable although he independently determines that for the purposes of the third-party action, the defendant is not liable to the plaintiff. Even if the question of liability is determined consistently, the judge and the jury may still disagree as to the amount of damages. ${ }^{54}$

An amendment providing for removal presents the most satisfactory solution to the problem of double litigation where a claim for contribution or indemnity against the United States arises out of an

62 The federal courts, in adopting a flexible approach, have permitted parallel trials to proceed before the presiding judge and a jury, and have employed the aid of special interrogatories where confusion might otherwise result, and have worked out solutions where other difficulties have arisen. They have been able to do this because both the original action and the claim against the United States were heard in a federal court which could preserve both the limitations of the Federal Tort Claims Act and the right to jury trial in the private dispute by allocating one aspect of the case to a jury and the other to the district judge.

City of Pittsburgh v. United States, 359 F.2d 564, 568 (3d Cir. 1966). See FED. R. Civ. P. 38, 39, 42(b); United States v. Yellow Cab Co., 340 U.S. 543 (1951); D.C. Transit Sys., Inc. v. Slingland, 266 F.2d 465 (D.C. Cir.), cert. denied, 361 U.S. 819 (1959); Schetter v. Housing Authority, 132 F. Supp. 149 (W.D. Pa. 1955) (advisory jury); United States v. Schlitz, 9 F.R.D. 259 (E.D. Va. 1949); Englehardt v. United States, 69 F. Supp. 451 (D. Md. 1947).

53 See Englehardt v. United States, 69 F. Supp. 451 (D. Md. 1947). Plaintiff brought an action against the United States and a private defendant as joint tortfeasors. The private defendant moved to dismiss the action against him on the ground that in an action against the United States under the Tort Claims Act, the nonjury trial provision precludes the joinder of another defendant who would be entitled to a jury trial. The court dismissed this argument with the observation that the Federal Rules of Civil Procedure provide sufficient flexibility to permit concurrent or, if necessary, separate trials. Id. at 455 .

54 See D.C. Transit Sys., Inc. v. Slingland, 266 F.2d 465 (D.C. Cir.), cert. denied, 361 U.S. 819 (1959), where plaintiff joined the Transit Company and the United States as defendants. The jury found that the Transit Company was liable to the plaintiff for $\$ 25,000$. The judge reduced this amount by remittitur to $\$ 15,000$ but found, as the trier of fact in the action against the United States, that the government was liable for only $\$ 10,000$. 
otherwise nonremovable state court action. One trial, conducted in the federal court, has the advantage of resolving all claims arising out of one incident without duplication of effort while permitting the United States to litigate the question of its liability in accordance with the conditions imposed by Congress. Although only a small number of cases are likely to be affected by such legislation, the judicial economy which will be promoted in these cases will certainly justify this new approach. 